\title{
Camping Area and Dock with Viewpoint to Promote Sustainable Ecotourist in the Ticcllacocha Lagoon, Tanta-Peru
}

\author{
Doris Esenarro, Francisca Cabello, Pedro Amaya, and Carlos Vargas
}

\begin{abstract}
Ecotourism is an alternative to practice tourism without causing negative impacts to the environment, enjoying the wonderful environment that nature itself offers us.

The main objective of this proposal is to create a camping area and a dock with viewpoint in the Ticllacocha lagoon, in the district of Tanta. This is due to the fact that currently Tanta does not have a lodge area for visitors who develop adventure tourism in the area. One of the main objectives through this project is to provide in an equitable manner, throughout the whole area, opportunities for learning and interaction between visitors, the local population and their environment, strengthening interest in the conservation of natural and cultural values of the area. To achieve the proposed objective, it is essential to know the tourist attractions that the Tanta district possesses.
\end{abstract}

Index Terms-Ecotourism, pier, ecotouristic viewpoint, Peru, Ticcllacocha lagoon.

\section{INTRODUCTION}

Biological and natural diversity sustains life and the economy, especially in a country like ours, in which natural capital is not only an important element of natural identity, but also as a fundamental part of our economy and culture. The ecosystems provide a service called scenic beauty (landscapes), on which the tourist activity that has generated, based in foreign currency, US \$4,895 million in 2018. In this sense, cultural, natural and heritage resources are part of a network of great value and wealth, which can be promoted and commercialize in a sustainable way, with the aim of improving the socio-economic well-being of local populations in the destinations and the conservation of the resources (Castellanos Verdugo et al., 2013). For this, it is important to coordinate all the stakeholders involved or that could be affected by the development of tourism through cultural, natural and / or heritage elements in a specific geographical destination and economic, organizational or

Manuscript received October 21, 2019; revised March 15, 2020.

Doris Esenarro and Pedro Amaya are with the Faculty of Geographical, Environmental and Ecotourism Engineering, Federico Villarreal National University, 51-1 Lima, Peru (e-mail: desenarro@unfv.edu.pe, desenarro@unfv.edu.pe).

Francisca Cabello was with Faculty of Geographical, Environmental and Ecotourism Engineering, Federico Villarreal National University, 51-1 Lima Peru (e-mail: 2015233705@unfv.edu.pe).

Carlos Vargas is with the Faculty of School of Architecture and Urbanism, Federico Villarreal National University, 51-1 Lima, Peru (e-mail: 2019316991@unfv.edu.pe). technological aspects.

In this particular case, the proposal will have a bioclimatic construction within it, considering that "the bioclimatic architecture consists of the design and operation of buildings and urban environments taking into account the weather and natural resources of the environment (natural light, wind, vegetation, etc.) [1]. The objective of the Bioclimatic Architecture is to provide a habitable environment for the building user with a minimal impact on the environment in terms of energy consumption, landscape integration, noise levels, pollutant emissions throughout the life of the building such as: design, construction, exploitation and dismantling if necessary" (Simulations and Projects - Knowledge from simulation).

Through this proposal entitled: "Nature-man confidence, camping area and dock in the Ticcllacocha lagoon" addressed to people who develop adventure tourism; seeks to promote the development of activities such as mountaineering, mountain biking, hiking, horseback riding, rappelling and other activities in the Ticcllacocha lagoon in the district of Tanta, Yauyos- Lima. This proposal has as main objective to revalue the space in order to give it a touristic value to the area and at the same time improve the quality of life of the population of Tanta generating a higher income.

The proposal is developed in the district of Tanta, province of Yauyos [2], in the department of Lima, under the administration of the Regional Government of Lima-Provinces. It is located in the northern part of Yauyos province, between the geographical coordinates $12^{\circ} 00^{\prime} 00^{\prime}$ $12^{\circ} 07^{\prime} 30^{\prime}$ ' 'south latitude and $75^{\circ} 52^{\prime} 30^{\prime}$ ' - 76 $07^{\circ} 30^{\prime}$ ' 'west longitude. The capital of the district is at an altitude of 4,268 meters above sea level, it has a territorial area of $347.15 \mathrm{~km} 2$, has a minimum climate of $9^{\circ} \mathrm{C}$, winds of the $\mathrm{N}$ at $16 \mathrm{~km} / \mathrm{h}$, humidity of $27 \%$ and has a population of 479 inhabitants (INEI, 2017).

Between 1850 and 1901 the community of Tanta is formed in the designated area of Hatuncancha, which years later was called San Antonio de Hatuncancha, and later on to be known as Tanta because in some caves located on the shores of the River Warku bread marketed (Tanta in Quechua) of Jauja.

Tanta is a small district which is located near Huancaya, but nevertheless it has not managed to bulge in its economic share since the influence of tourists is concentrated in the district of Huancaya [3]. For this reason, this proposal seeks to promote tourism in Tanta. It has a wide variety of touristic resources, such as lakes, lagoons and snowfall, however it is not as empowered or been promoted as other districts in the province of Yauyos. 


\section{METHOD}

\section{A. The First Stage}

This is an evaluation of the current situation in which the district of Tanta is located. This has allowed to elaborate the diagnosis of the starting point, of the infrastructure and travel services within the area and also the interest and expectations of the local population on tourism. This information was gathered on the web.

\section{B. The Second Stage}

The second stage allows the development of the model, size and material for the implementation of the camping area and the Pier-Viewpoint in the Ticcllacocha Lagoon. On the other hand, we proceed to the selection, delimitation and mapping of the area of interest.

\section{Final Stage}

The third stage consists in the systematization of the information to lead off with the elaboration of the proposal.

\section{RESULTS}

The solar radiation in Lima goes from $5.0 \mathrm{~W} / \mathrm{m}^{2}$ in May to $7.5 \mathrm{~W} / \mathrm{m}^{2}$ in November. These records show a high solar radiation so the application of solar panels is the most suitable for their energy use [4].

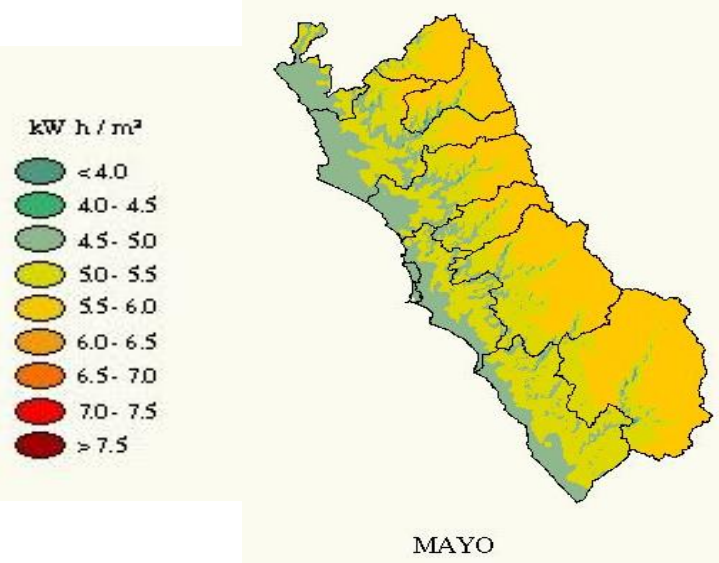

Fig. 1. Solar radiation in Lima province in May.

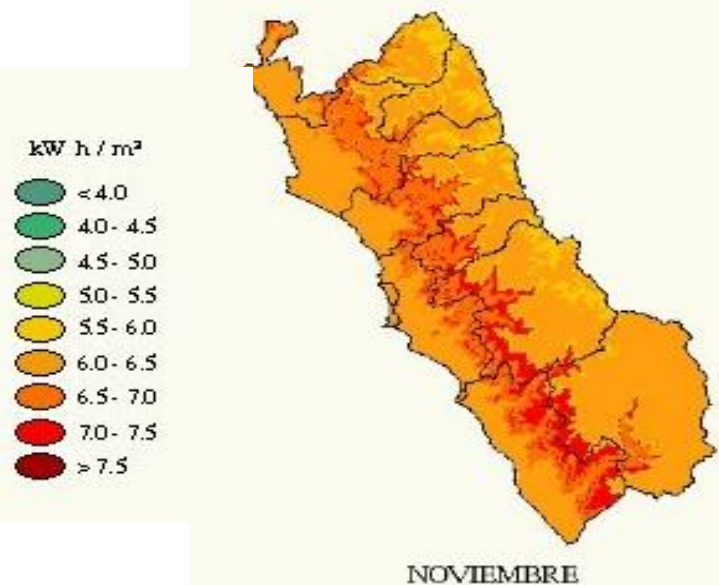

Fig. 2. Solar radiation in Lima province in November.
The climate classification of the district of Tanta is Rainy Weather, Semi Frigid B(o,i)B3H3 and Semi-dry Cold Weather C(i)CH3.

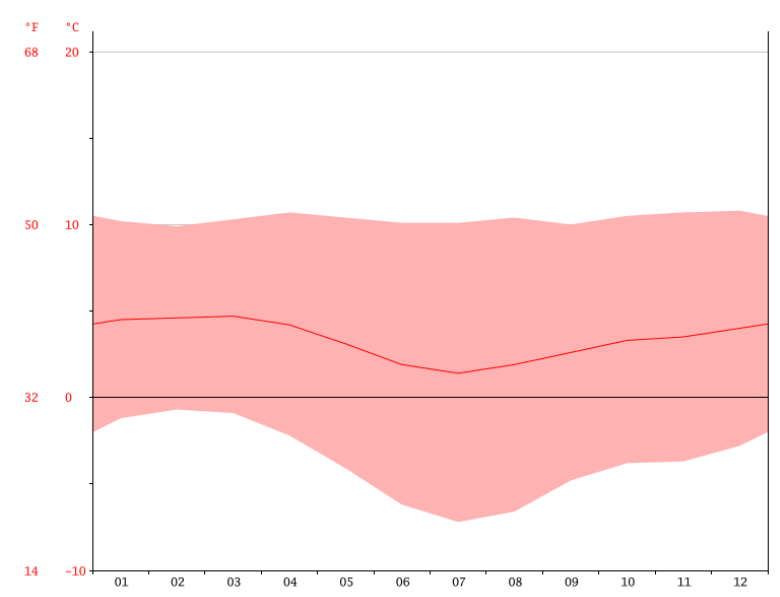

Fig. 3. Average temperature of the year in Tanta district is $4.7^{\circ} \mathrm{C}$.

The district of Tanta has tourism resources that display its potential as a tourist destination to mainly develop mountain tourism, but it lacks infrastructure to be considered tourist attraction [5], [6]. This proposal is proposing to implement a camping area that allows, both the local population as well as the tourist, who develop this type of tourism to spend the night in the Ticcllacocha lagoon, with a main view of the snowy Ticlla.

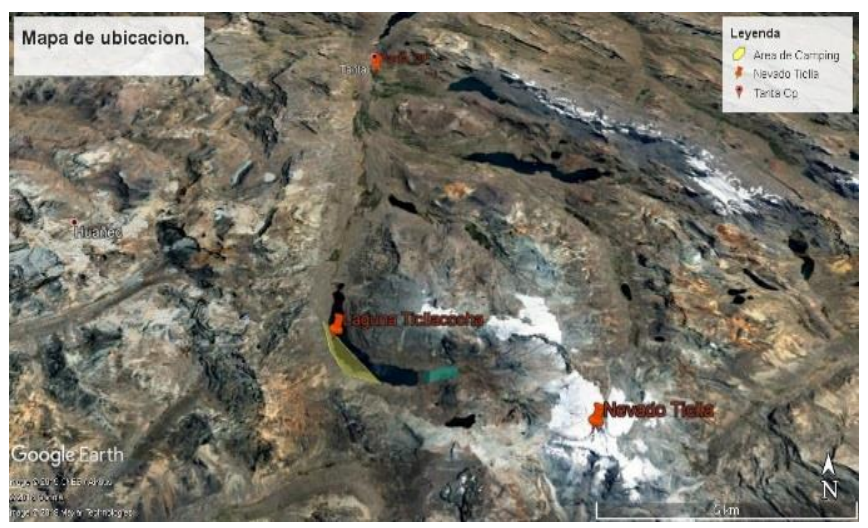

Fig. 4. Village location.

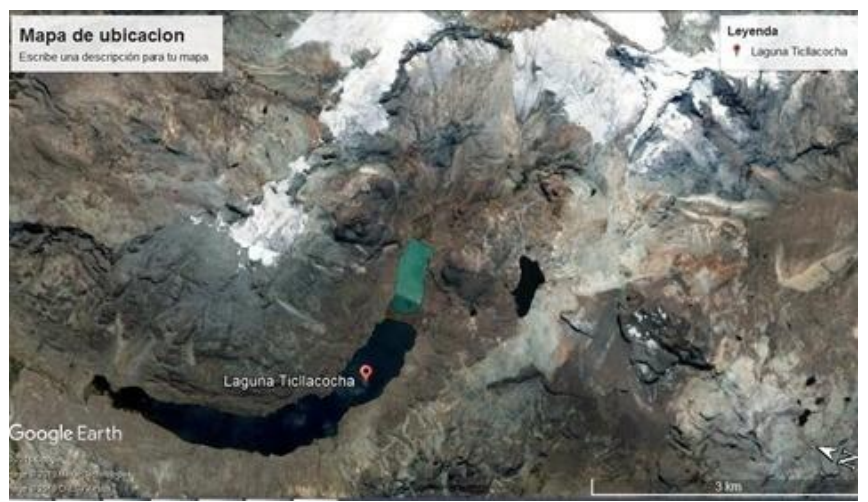

Fig. 5. Lagoon location.

The tourist attractions of the district of Tanta - Yauyos Province are [7]:

1) Tanta Waterfall

2) Tanta Lagoon

3) Llicocca Lagoon 
4) Ticllacocha Lagoon

5) Chuspicocha Lagoon

6) Suerococha Lagoon

7) Cuyacocha Lagoon

8) Piscococha Lagoon

9) Aquipallca Snowy

10) Ticlla Snowy

Once the recognition of all the water resources in zone 1 of Tanta has been carried out, the proposal for the implementation of the camping area in the main lagoon Ticcllacocha is proposed.

A Pier-Viewpoint will be implemented in the Ticcllacocha lagoon, this infrastructure will have a restaurant area, souvenirs, among other attractive.

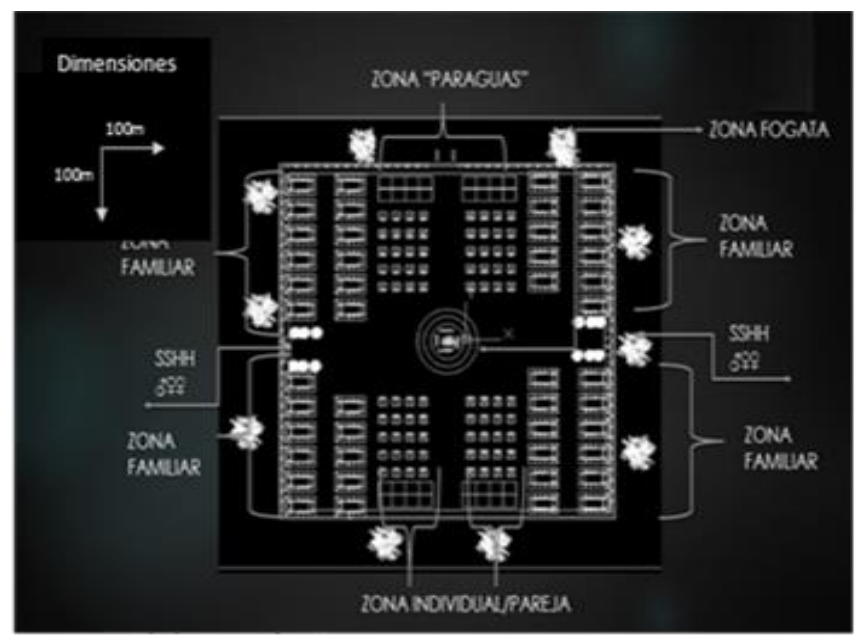

Fig. 6. Camp area distribution.
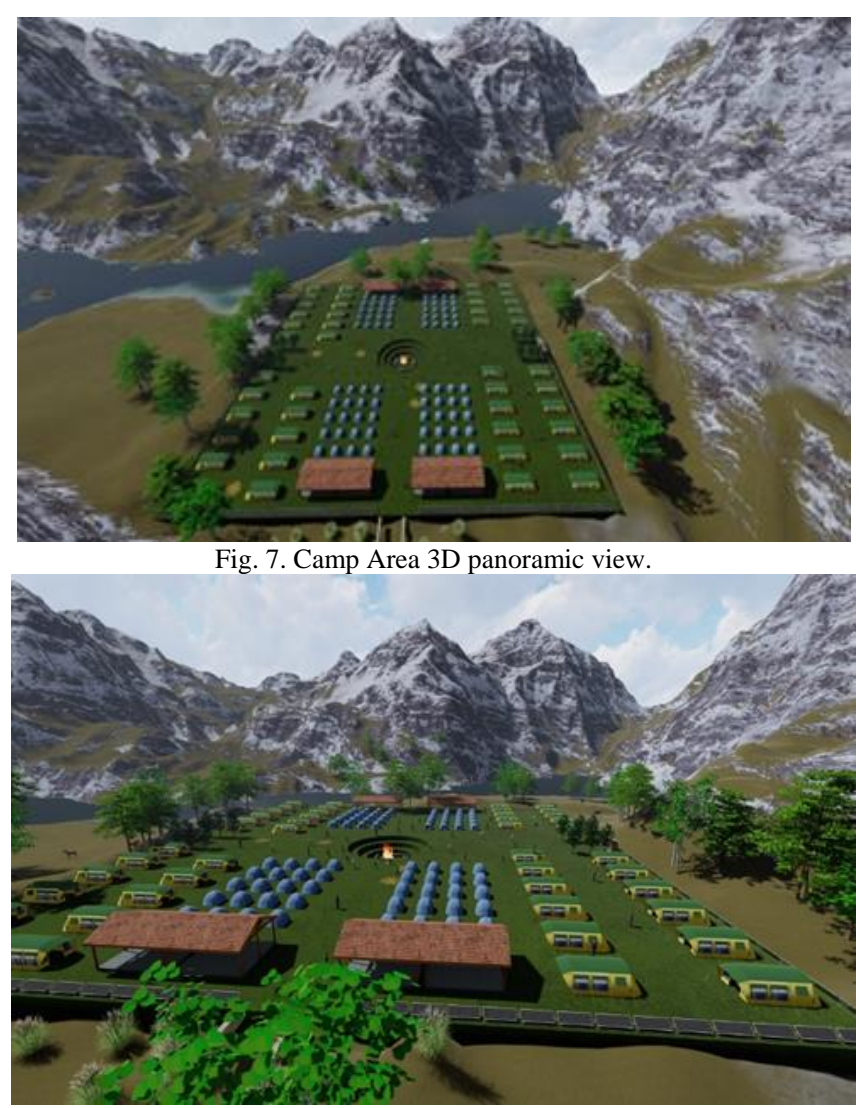

Fig. 8. Camp area overlooking the snowy Ticlla.

A proposal is placed to implement a camping area on a land 100 meters long by 100 meters wide, with tent areas for family, individual or couples, with a recreational area that has a platform campfire area to avoid forest fires, in addition with clean and self-sustainable technologies of ecological dry toilets and solar panels [6].

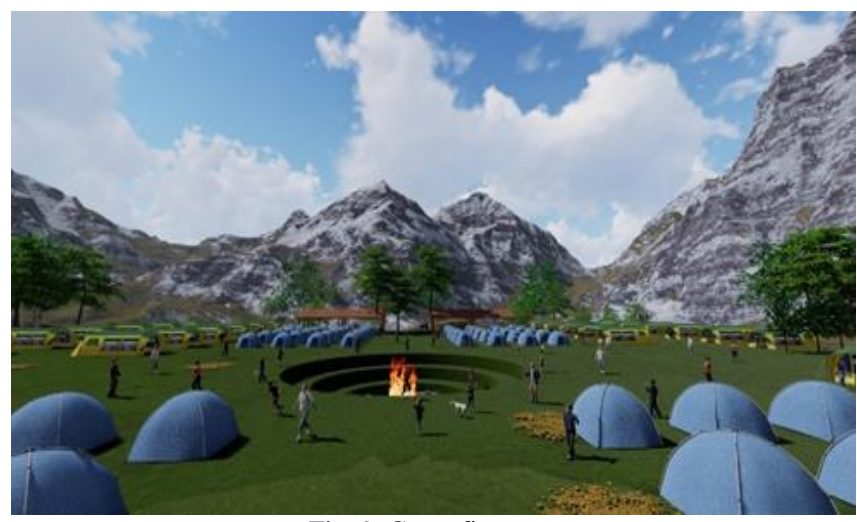

Fig. 9. Camp fire area.

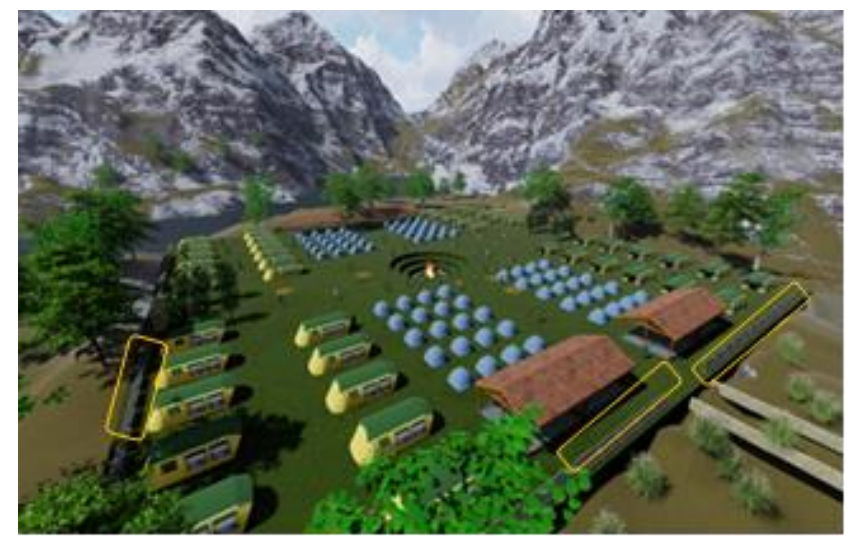

Fig. 10. Solar panels in the Camp Zone.

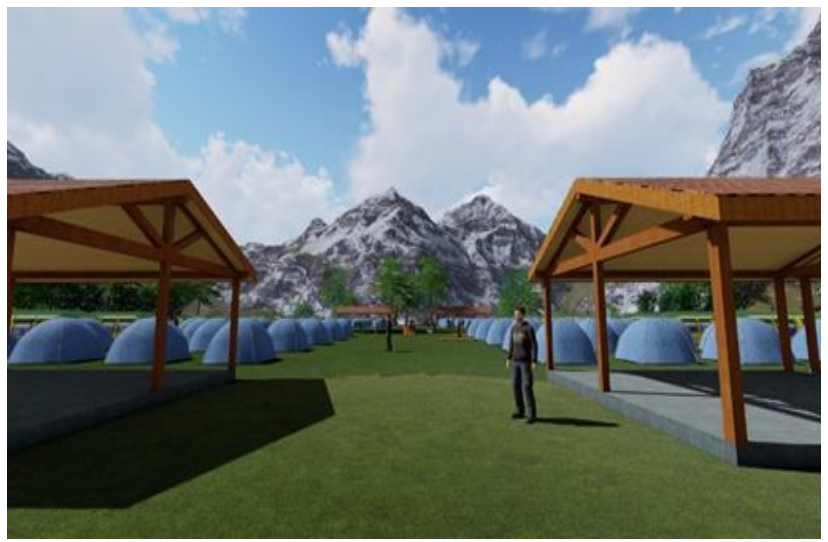

Fig. 11. "Umbrella" Zone in the Camp Zone.

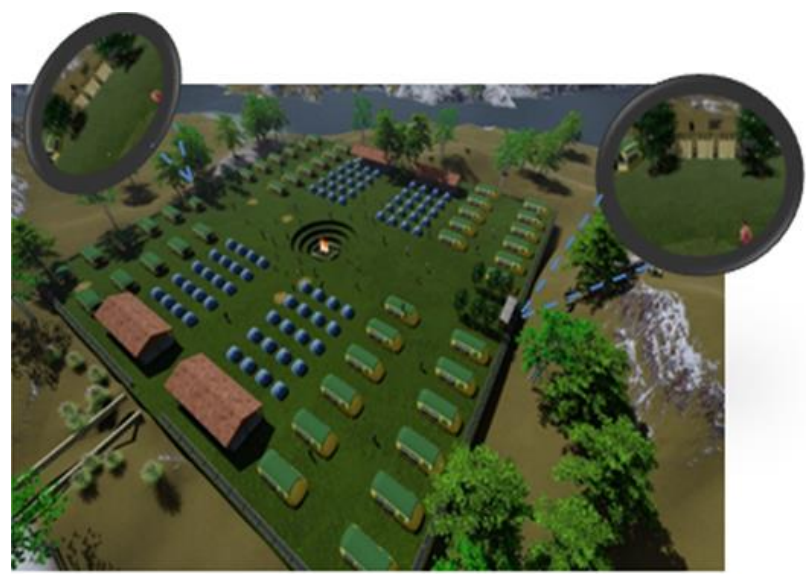

Fig. 12. Dry toilets in the Camp Zone. 
The Camp Zone is established in the Ticcllacocha Lagoon with a main view of the Ticlla snowy mountain.

Throughout this implementation, it's proposed a Pier-Viewpoint in Ticcllacocha Lagoon with restaurant services that is located in the upper part of the Dock, through this a $50 \%$ increase in tourists will be achieved in the District of Tanta Province of Yauyos [8]. Below, you can see some images of the map of the Pier with Viewpoint and the Restaurant.

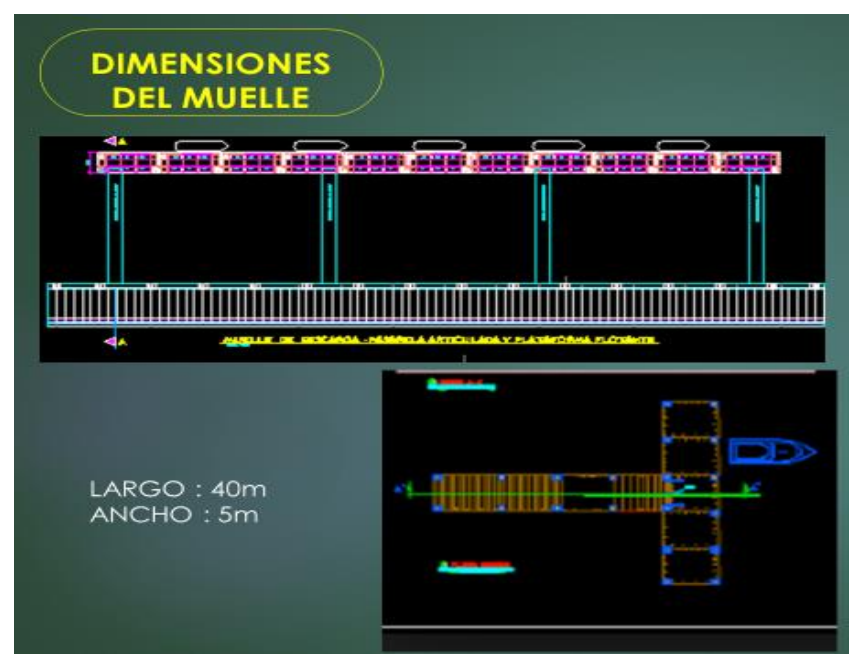

Fig. 13. Pier-viewpoint dimensions.

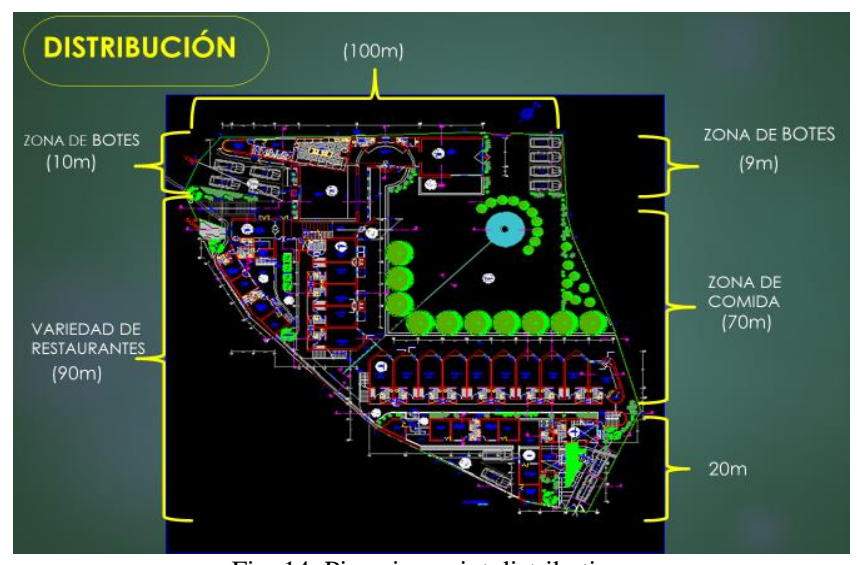

Fig. 14. Pier-viewpoint distribution.

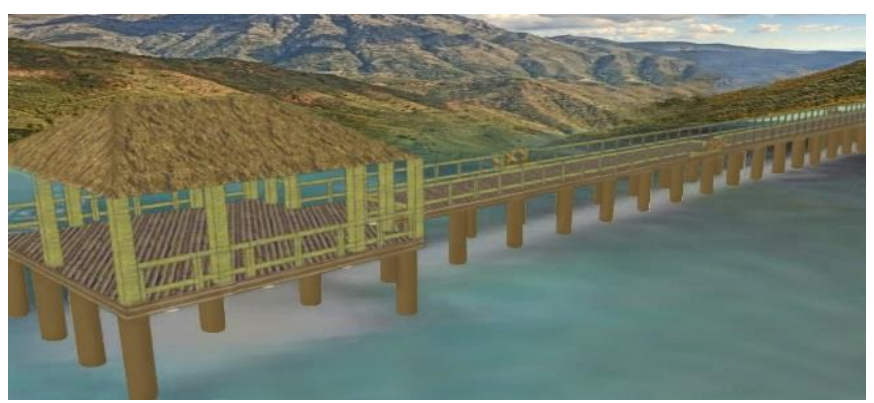

Fig. 15. 3D of the pier-viewpoint.

Through the development of ecotourism attractions (adventure tourism) and the implementation of a camping area, the Tanta district, as a tourist attraction, will have a greater economic income. Being

Tanta the district on the way in which the eco tourists will be able to furnish food as well as of implements for the camping zone.

This proposal will be made with materials from the area and at the same time the infrastructure will not harm the environment [9], [10]. This will be coordinated with the local residents and stakeholders.

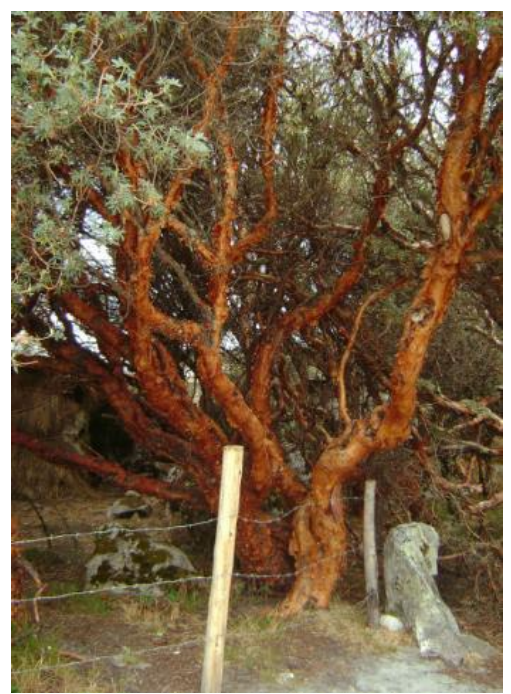

Fig. 16. Queñual tree, material used for the construction of the Dock.

\section{CONCLUSIONS}

1) Through the implementation of the two constructions already mentioned, a greater flow of tourists will be reached, generating economic income development due to the increase of visitors and therefore an improvement of the quality life of Tanta's population [11].

2) The achievement of the new infrastructure will generate greater tourism activity in Tanta-Yauyos.

3) It seeks to give value to the area and at the same time create awareness to the population of Tanta regarding the environmental care.

4) Through this proposal, sustainability is achieved for the Ticcllacocha Lagoon through the installations for clean energy fulfilled (solar panels and dry toilets) [12].

5) This proposal will generate foreign exchange, increasing the economy for both regional as national.

\section{CONFLICT OF INTERESTS}

This research was carried out as a contribution to the knowledge, society and academic purposes in a multidisciplinary environment, "The authors declare that we have no conflicts of interest".

\section{AUTHOR CONTRIBUTIONS}

A carried out the research design; $\mathrm{AB}$ analyzed the data; $\mathrm{AC}$ carried out the design of the ABC and D study area. We carried out the exploratory field study, the authors' contribution is reflected in all the research approved in its

\section{REFERENCES}

[1] J. R. Aguilar, "A review of acoustic design criteria for school infrastructure in Chile," Journal Construction Engineering, vol. 34, no. 2, Santiago, CHILE, 2018.

[2] Economic Development Cooperation Program Secretariat of State for Economic Affairs SECO. (2014). Manual for tourism product planning, Lima, Swisscontact. [Online]. Available: https://www.mincetur.gob.pe

[3] General Directorate of Evaluation, Valuation and Financing of Natural Heritage, of the Ministry of Environment. Inventory and evaluation of Natural Heritage in the Nor Yauyos Cochas Landscape Reserve, Lima, MINAM. 2011. [Online]. Available: http://www.minam.gob 
[4] SERNANP, Master Plan of the Nor Yauyos Cochas Landscape Reserve 2016-2020, Lima. (2016). [Online]. Available: http://old.sernanp.gob.pe

[5] A. P. Delgadillo et al., "Community sustainability and tourism in the pooled towns route, Oaxaca, Mexico," International Journal of Environmental Science and Development, 2016, vol. 7, no. 2, pp. 156-159.

[6] Abdulrahman Sa'adu Danjaji \& Mariani Ariffin, "Green infrastructure policy for sustainable urban development," International Journal of Environment and Sustainable Development, 2017, vol. 16, no. 2, pp. 112-127.

[7] T. Buragohain, "Impact of solar energy in rural development in India," International Journal of Environmental Science and Development, 2012, vol. 3, no. 4, pp. 334-338.

[8] Q. Y. Dong and T. Futawatari, "A study for renewable energy generation and sustainable development in China," International Journal of Environmental Science and Development, 2015. vol. 6, no. 3, pp. 191-195.

[9] V. C. Drosos et al., "Sustainable development and exploitation of semi-mountainous area in Greece," International Journal of Environmental Science and Development, 2016, vol. 7, no. 6, pp. 473-479.

[10] S. Americo. (2008-2012). Tourist Use Plan RPNYC. [Online]. Available: http://old.sernanp.gob.pe

[11] C. F. S. Rojas et al. (2008-2012). Tourist and Recreational Use Plan of the $R P N Y C$ [Online]. Available: https://es.scribd.com/document/75306999/

[12] H. Elimam and H. Alattas, "The contribution of Saudi Woman in environmental development," International Journal of Environmental Science and Development, vol. 7, no. 2, pp. 151-155, 2016.

Copyright $\odot 2020$ by the authors. This is an open access article distributed under the Creative Commons Attribution License which permits unrestricted use, distribution, and reproduction in any medium, provided the original work is properly cited (CC BY 4.0).

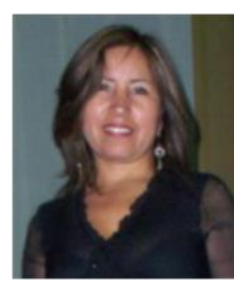

Doris Esenarro is system engineer. She got the bachelor of architecture of the National University Federico Villarreal, Lima, Peru, professor of Faculty of Environmental Engineering of the University Federico Villarreal, professor of the Graduate School EUPG. Her contribution is proposal of clean technologies for the project.

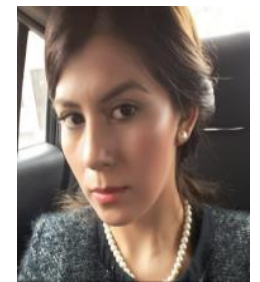

Francisca Cabello is student at the Faculty of Ecotourism Engineering of the National University Federico Villarreal. She develops consulting social and sustainable projects. Her contributions are development of the proposal of the project.

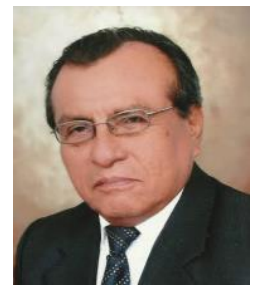

Pedro Amaya is economist of the National University Federico Villarreal, Lima, Peru 1990. He has worked as professor of the University Federico Villarreal. His contributions are evaluation of the social, environmental and economic viability of the project.

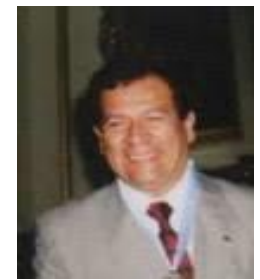

Carlos Vargas is architect of the National University Federico Villarreal, Lima, Peru 1980. He has worked as main professor of the architecture faculty of the University Federico Villarreal. He developed social and sustainable projects. His contributions are architectural design of the project. 